\title{
Проблема і зміст професійної освіти інструкторів з фізичної культури сільських і селищних рад, об’єднаних територіальних громад
}

\section{Тетяна Дорофрєєва}

\author{
Харківська державна академія фрізичної культури, Харків, Україна
}

Анотація. Динаміка суспільних процесів вимагає від системи безперервної фізкультурної освіти (підготовка, перепідготовка і підвищення кваліфрікації кадрів) одночасно її здатності до системно-функціонального оновлення та саморозвитку галузі в умовах зовнішньої нестабільності в українському суспільстві. Мета. Визначити проблеми кадрового забезпечення, обсяг освітніх вимог до підготовки інструкторів-методистів з організації фрізкультурнооздоровчої роботи територіальних громад, а також сучасні підходи до формування змісту професійної компетентності генерації як майбутніх, так і вже працюючих інструкторів. Методи. Аналіз наукової літератури, абстрагування, синтез, індукція та дедукція, ідеалізація та узагальнення. Результати. Обґрунтування існуючої потреби, а також поданий спосіб педагогічного проєктування були застосовані у процесі розробки освітньо-професійної програми інструкторів-методистів з організації фрізкультурно-оздоровчої роботи територіальних громад рівня магістр, а також внутрішнього Стандарту підвищення кваліфікації нині працюючих інструкторів фрізичної культури сільських і селищних рад, об'єднаних територіальних громад. На сьогодні виникла потреба шляхом стандартизації освіти удосконалити вимоги до змісту, обсягу та якості вищої освіти фрахівців, це стосується й інструкторів-методистів з організації фрізкультурно-оздоровчої роботи територіальних громад. Адже у Довіднику кваліфікаційних характеристик професій працівників вказано, що посада «Методиста 3 фізичної культури» передбачає наявність освітнього рівня магістр. Тож існує завдання забезпечити становлення генерації інструкторів-методистів як фахівців, здатних досягати поставленої мети в різних ситуаціях шляхом опанування інноваційних методів вирішення професійних завдань. Ця проблема може бути вирішена через створення освітньопрофесійних програм рівня магістр спеціалізації «Інструктор-методист

з організації фрізкультурно-оздоровчої роботи територіальних громад» і Стандарту

підвищення кваліфікації нині працюючих інструкторів фрізичної культури сільських

і селищних рад, об'єднаних територіальних громад.

Ключові слова: інструктори, освіта, стандарт, громади, проєктування.

\section{Tetiana Dorofieieva}

\section{THE ISSUE AND CONTENT OF PROFESSIONAL EDUCATION OF PHYSICAL CULTURE INSTRUCTORS OF VILLAGE AND SETTLEMENT COUNCILS AND UNITED TERRITORIAL COMMUNITIES}

Abstract. The dynamics of social processes requires from the system of continuing physical education (training, retraining, and advanced training) both its ability to systemic functional renewal and self-development of the industry under conditions of external instability in Ukrainian society. Objective. To identify the issues of staffing, the amount of educational requirements for the training of instructors-methodologists of the organization of physical culture and healthenhancing work in territorial communities, as well as modern approaches to forming the content of professional competence of both future and existing instructors. Methods. Analysis of scientific literature, abstraction, synthesis, induction and deduction, idealization and generalization. Results. Substantiation of the existing need as well as the given method of pedagogical design were used to develop the Master's level educational and professional training program for instructorsmethodologists of the organization of physical culture and health-enhancing work in territorial communities as well as the internal Standard of professional development for currently working physical culture instructors of village and settlement councils and united territorial communities.

Dorofieieva T. The issue and content of professional education of physical culture instructors of village and settlement councils and united territorial communities. Theory and Methods of Physical education and sports. 2021; 3: 60-66

DOl: 10.32652/tmfvs.2021.3.60-66
Дорофєєва Т. Проблема і зміст професійної освіти інструкторів 3 фрізичної культури сільських і селищних рад, об'єднаних територіальних громад. Теорія і методика фрізичного виховання і спорту. 2021; 3: 60-66

DOI: 10.32652/tmfvs.2021.3.60-66
Вступ. Посада інструктора, яку обіймає відповідний фрахівець у громаді, в документах Міністерства молоді та спорту України має назву «|нструктор з фрізкультури сільських і селищних рад, об'єднаних територіальних громад» [18]. У Класифрікаторі просресій України ДК 003:2010 вона названа «Інструктор з фрізкультури» під вихідними даними: код КП 3475 , док ЗКПП ТР 22831, випуск ДКХП 85 [7]. Важливість цієї посади можна підкреслити таким фрактом: у Республіці Польща, яка $є$ для нас прикладом місцевого самоврядування, тригером змін в гмінах, подібних до об'єднаних територіальних громад (ОТГ), став проєкт «Moje Boisko - ORLIK 2012» [26, 29, 33]. Саме на цих спортивних об'єктах усі заходи безпосередньо організують і проводять так звані аніматори, які виконують функції, подібні до діяльності інструкторів наших ОТГ $[30,31]$.

Загалом, як у Республіці Польща, так і пізніше в Україні цілком поділяють і підтримують ставлення і підходи до поширення масового і результативного спорту [21, 22], у тому числі його розвитку на регіональному рівні [25, 27, 34].

Однак, як зауважує М. В. Дутчак, протягом останнього десятиріччя у системі кадрового забезпечення вітчизняної сфери фрізичної культури і спорту було накопичено багато суперечностей між реальним станом справ та запитами суспільства і новими можливостями для їх задоволення. Саме усунення наявних протиріч має становити базис для зростання кількості персоналу, спроможного до успішного вирішення професійних завдань на основі використання наукових знань і передової практики роботи та з урахуванням нових викликів [6].

Під поняттям «кадрова політика» у ссрері спорту розуміють діяльність державних органів влади, спрямовану 
Today there is a need to improve the requirements for the content, scope, and quality of higher education of professionals by standardizing education, this also applies to instructorsmethodologists of the organization of physical culture and health-enhancing work in territoria communities. The reason is that the Handbook of Qualification Characteristics of Occupations states that the Methodist of Physical Culture position requires a master's degree. Therefore, there is an objective to ensure the formation of a generation of instructors-methodologists as professionals who are able to achieve the goal in various situations by mastering innovative methods of solving professional tasks. This issue can be resolved by developing the Master's level educational and professional training program for instructors-methodologists in the organization of physical culture and health-enhancing work in territorial communities as well as the internal Standard of professional development for currently working physical culture instructors of village and settlement councils and united territorial communities.

Keywords: instructors, education, standard, communities, designing.

на формування, удосконалення, впровадження стандартів, професійних вимог до службовців, педагогічних та інших працівників галузі, критеріїв їх підбору, підготовки та перепідготовки, підвищення рівня ділової кваліфікації, раціонального використання кадрового потенціалу та його збереження на основні кількісно-якісних прогнозів і перспектив розвитку фізичної культури і спорту в Україні [8].

Нині в умовах, що склались, науковцям і практикам необхідно сформувати та в подальшому реалізувати сучасну стратегію розвитку фрахової освіти у сфері фрізичної культури і спорту в Україні. Саме вона слугуватиме методологічним орієнтиром для удосконалення системи галузевої вищої освіти [6]. I серед головних завдань системи кадрового забезпечення галузі є потреба саме шляхом стандартизації освіти фрахівців різного профрілю суттєво удосконалити вимоги до змісту, обсягу та якості вищої освіти [8]. Зазначимо, що міжнародна практика встановлення стандартів вже існує у вказаній галузі, але вона поширена власне на процеси фрізичного виховання [35].

Фізичній культурі і спорту притаманні такі кадрові процеси, як оволодіння професією, включення у сферу професійної діяльності, подальше професійне навчання та підвищення кваліфікації, становлення професіонала, посадове зростання, узагальнення та передача передового професійного досвіду, творчий генезис фахівця-професіонала [12]. Управління кадрами - це цілеспрямований, спланований, координуючий і організуючий вплив суб'єктів управління на кількісні та якісні зміни кадрового складу в часі й просторі шляхом ви- значення потреби в кадрах і коригувальних дій, щоб наявні кадри відповідали потребам у них з метою досягнення організацією поставлених цілей [11].

Проте динамічність суспільних процесів вимагає в системі безперервної фрізкультурної освіти (підготовка, перепідготовка і підвищення кваліфікації) одночасно її здатності до системно-функціонального оновлення та саморозвитку галузі в умовах зовнішньої нестабільності в українському суспільстві [8].

Мета дослідження - виявити проблеми кадрового забезпечення, обсяг освітніх вимог до підготовки інструкторів-методистів 3 організації фізкультурно-оздоровчої роботи територіальних громад, а також сучасні підходи до формування змісту професійної компетентності генерації як майбутніх, так і вже працюючих інструкторів.

Методи дослідження: аналіз наукової літератури, абстрагування, синтез, індукція та дедукція, ідеалізація та узагальнення.

Результати дослідження та їх обговорення. У період з 1992 по 2009 р відбулось різке зменшення інструкторів з фрізичної культури сільських і селищних рад майже у 20 разів. Якщо у 1992 р. нараховувалось 15256 фрізкультурних працівників на селі, то в 2009 р. їх кількість становила 787 осіб.

На думку деяких учених [8], скорочення працівників у підсистемі «Масовий спорт серед сільського населення» обумовлене зміною державного політичного курсу у сільському господарстві, який передбачав перехід до ринкових механізмів господарювання, зменшення обсягів державного фрінансування соціальної сфрери села, неесективного застосування і використання наявного адміністративного ресурсу певної території, а також неспроможності, а подекуди і явного небажання, нових власників вкладати кошти у розвиток соціальної інфраструктури села і, передовсім, у розвиток фізичної культури і спорту.

Протягом вказаного періоду на селі зменшилась кількість інструкторів з фрізичної культури на 46,3 \%, а керівників і викладачів фрізичного виховання професійно-технічних навчальних закладів - на 14,8 \% [8].

Заняття з понад 66000 осіб, які займались різними видами спорту на селі у 2019 р., проводили 664 штатні тренери. До фрізкультурно-оздоровчої роботи у громадах було залучено 426468 осіб, які займались у позанавчальний час. Щодо забезпечення фрахівцями, то 46 закладів вищої освіти (3В0) проводять підготовку і підвищення кваліфікації цієї категорії кадрів. Загалом підвищення кваліфікації спроможні організовувати ті 3В0, які мають право на здійснення освітньої діяльності вже на першому рівні вищої освіти 3 підвищення кваліфікації фахівців за спеціальністю 017 «Фізична культура і спорт» [3]. До цього рівня належать нині працюючі Інструктори з фрізкультури сільських і селищних рад, об'єднаних територіальних громад. Тож потрібно знайти також дієву форму підвищення їхньої кваліфрікації за першим рівнем вищої освіти.

Між тим визнається: «€ необхідним приведення до вимог сучасності та європейських стандартів Класифрікатора професій та Довідника кваліфікаційних характеристик професій працівників, Випуск 85 «Спортивна діяльність» [3]. Вирішення зазначеної проблеми має відбуватись відповідно до Європейських рамок кваліфрікацій як основи інтеграції національних систем освіти [1]. В ухвалі колегії Міністерства молоді та спорту України передбачено перспективу внесення змін до Довідника кваліфрікаційних характеристик професій працівників, Випуск 85, з урахуванням сучасних умов та вимог ринку праці, зокрема щодо визначення кваліфікаційних характеристик фрахівців, які проводять 
фрізкультурно-оздоровчу діяльність у територіальних громадах [17].

Мова йде про забезпечення становлення такого конкурентоспроможного фрахівця фрізичної культури, який здатен досягати поставленої мети в різних ситуаціях через опанування методів вирішення інноваційних професійних завдань, наявності певних і необхідних якостей особи [20].

Процес створення 1469 ОТГ, які охоплюють 5-7 і більше населених пунктів і в яких проживають десятки тисяч мешканців, змінив вимоги до змісту та якості професійної підготовки інструкторів, що вимагає опанування особою освітнього рівня магістр, як здатної до виконання різних видів інноваційної діяльності.

Згідно 3 даними офріційного інформаційного довідника, в Україні у 2019 р. налічувалось 783 штатних інструктори фрізкультури сільських і селищних рад, а також об'єднаних територіальних громад, у тому числі 72 особи жіночої статі і 201 особа, яка мала спеціальну вищу освіту з фізичної культури і спорту [18]. Але їх розподіл по областях є помітно нерівномірним, що важко пояснити (табл. 1).

В інфрормаційному довіднику «Україна спортивна», де подано відомості, включені до таблиці 1, відсутній вкрай необхідний для розуміння різновекторних процесів змін коментар щодо значного розбігу в кількості інструкторів ффізичної культури по областях. Не подано причини значної кількості інструкторів по окремих областях, як наприклад, в Одеській і Хмельницькій, так і їх повної відсутності (Львівська і Тернопільська), а також фракторів, що призводять до зменшення кількості інструкторів на наступний рік в половині областей тощо.

Нагальна потреба обґрунтування і впровадження в діяльність спеціалізованих ЗВО професійного стандарту освітнього рівня магістр у тому числі для інструктора фрізичної культури сільських та селищних рад, а також об'єднаних територіальних громад зумовлена існуючою відсутністю вкрай потрібного стандартизованого підходу до визначення переліку їхніх трудових фуннкцій, а також загальних і спе-

Т а б л и ц я 1. Інструктори з фізкультури сільських та селищних рад, об'єднаних територіальних громад сіл, селищ, міст $[15,18]$

\begin{tabular}{|c|c|c|c|c|c|c|}
\hline \multirow{2}{*}{ Область } & \multicolumn{2}{|c|}{$\begin{array}{l}\text { Загальна кількість } \\
\text { інструкторів }\end{array}$} & \multicolumn{4}{|c|}{$\begin{array}{l}\text { Які мають спеціальну вищу освіту з фізичної } \\
\text { культури і спорту }\end{array}$} \\
\hline & $2018 \mathrm{p}$. & $2019 \mathrm{p}$. & $2018 \mathrm{p}$. & $\%$ & $2019 \mathrm{p}$. & $\%$ \\
\hline Вінницька & 47 & 39 & 27 & 57,45 & 24 & 61,54 \\
\hline Волинська & 6 & 4 & 3 & 50,00 & 0 & 0,00 \\
\hline Дніпропетровська & 26 & 20 & 5 & 19,23 & 6 & 30,00 \\
\hline Донецька & 17 & 14 & 10 & & & \\
\hline Житомирська & 6 & 10 & 3 & 50,00 & 5 & 50,00 \\
\hline Закарпатська & 1 & 1 & 1 & 100,00 & 1 & 100,00 \\
\hline Запорізька & 13 & 11 & 11 & 84,62 & 9 & 81,82 \\
\hline І̇вано-Франківська & 27 & 21 & 15 & 55,56 & 11 & 52,38 \\
\hline Київська & 41 & 41 & 31 & 75,61 & 31 & 75,61 \\
\hline Кіровоградська & 61 & 61 & 8 & 13,11 & 9 & 14,75 \\
\hline Луганська & 6 & 3 & 3 & 50,00 & 0 & 0,00 \\
\hline Львівська & 0 & 0 & 0 & 0,00 & 0 & 0,00 \\
\hline Миколаївська & 13 & 13 & 8 & 61,54 & 9 & 69,23 \\
\hline Одеська & 120 & 120 & 62 & 51,67 & 65 & 54,17 \\
\hline Полтавська & 64 & 59 & 20 & 31,25 & 12 & 20,34 \\
\hline Рівненська & 17 & 18 & 3 & 17,65 & 3 & 16,67 \\
\hline Сумська & 21 & 21 & 5 & 23,81 & 5 & 23,81 \\
\hline Тернопільська & 0 & 0 & 0 & 0,00 & 0 & 0,00 \\
\hline Харківська & 42 & 39 & 21 & 50,00 & 15 & 38,46 \\
\hline Херсонська & 75 & 81 & 32 & 42,67 & 30 & 37,04 \\
\hline Хмельницька & 150 & 150 & 0 & 0,00 & 0 & 0,00 \\
\hline Черкаська & 30 & 31 & 7 & 23,33 & 9 & 29,03 \\
\hline Чернівецька & 27 & 25 & 2 & 7,41 & 5 & 20,00 \\
\hline Чернігівська & 0 & 1 & 0 & 0,00 & 1 & 100,00 \\
\hline м. Київ & 0 & 0 & & 0,00 & & 0,00 \\
\hline В С ь ОГО & 810 & 783 & 277 & 34,20 & 261 & 33,33 \\
\hline
\end{tabular}

ціальних компетентностей, що мають їх забезпечувати.

На сьогодні існують затверджені кваліфікаційні характеристики «|нструктора $з$ фрізичної культури» [16]. Наказом Міністерства молоді та спорту України встановлено вимоги до фахівця, які лише частково відображають суть діяльності сучасного інструктора фрізичної культури сільських та селищних рад, а також об'єднаних територіальних громад. Саме тому, як свідчить перший досвід діяльності відділів громад, до компетенції яких входять питання фрізичної культури і спорту, і фрахівця (інструктора) в структурі цього відділу, має бути віднесений суттєво інший за обсягом більший перелік питань [9].

Очевидно, що існуючі нині посадові обов'язки в цілому окреслюють коло питань, пов'язаних зі змістом діяльності інструктора фізичної культури сільських та селищних рад, а та- 
кож об'єднаних територіальних громад. Однак, якщо порівняти їх з основними напрямами діяльності відповідних відділів громад та інструкторів 3 фрізкультури, то будуть помітні досить суттєві розбіжності, а саме - фактичний зміст діяльності інструктора є набагато більшим за обсягом, ніж це описано в існуючій посадовій інструкції (табл. 2).

Крім того, інструктор фрізичної культури часто буває єдиним спеціалістом профільного відділу громади, тож має потребу у відповідних знаннях, уміннях та компетентностях, які забезпечують увесь обсяг функцій, поданих у таблиці 2, що має бути відображено в освітньо-професійній програмі підготовки магістра. По-перше, і це відображено в кваліфікаційній характеристиці, він педагог, який проводить заняття 3 надання фізкультурноспортивних послуг. По-друге, він має виконувати значний обсяг різноманітної роботи з участі в розробці та виконанні комплексних програм і планів розвитку фізичної культури і спорту, вдосконалення матеріально-технічної бази для занять спортом тощо.
Очевидно, що значний обсяг вказаних нових функцій для фахівця (інструктора) повною мірою відповідає, магістерському рівню вищої освіти, тому за своїм змістом - це вже спеціалізація інструктора-методиста з організації фрізкультурно-оздоровчої роботи в територіальних громадах, а сама підготовка цієї категорії інструкторівметодистів має бути забезпечена за рахунок відповідних освітньопрофресійних програм у ЗВО.

Вивчення практики підготовки фрахівців аналогічного профрілю за кордоном свідчить про врахування вказаних особливостей у процесі їх освіти та підготовки. Так, М. В. Данилевич [2] відмічає, що до навчального плану ліценціату за спеціальністю «Спортивний інструктор» (в Україні - бакалаврату) Державної вищої професійної школи імені Станіслава Пігоня, що в м. Кросьне Республіки Польща, включено предмети «Управління спортивними та рекреаційними установами» та «Економіка спортивнорекреаційних установ».

Литовський спортивний університет пропонує бакалаврську програму (в Україні має назву - спеціалізація)
«Спортивний менеджмент» [2]. Консорціум семи університетів країн Європейського Союзу, включаючи Литовський спортивний університет, готує так званих «фрахівців нового покоління». У першому семестрі бакалаврату 3 фрізичного виховання та здоров'я передбачено модуль «Управління проєктами» (в обсязі 5 кредитів), у п'ятому семестрі - «Політика та управління у ссрері спорту та охорони здоров'я». Німецький спортивний університет м. Кельн серед п'яти бакалаврських програм пропонує «Спортивний менеджмент та комунікації в спорті» [2].

В українських спеціалізованих закладах вищої освіти протягом останніх років теж існує спеціалізація «Менеджмент фрізичної культури і спорту». Так, у Харківській державній академії фізичної культури підготовлено і реалізовано освітньо-професійну програму «Менеджмент і маркетинг у сфрері фрізичної культури та спорту» [10]. Л. Я. Чеховською [19] обґрунтовано вимоги до стандарту «Менеджер фітнес-сервісу». Важливо, що вказана тут практика одночасно узгоджується 3 європейською рамкою квалі-

Т а б л и ц я 2. Порівняння визначеним практиками спорту змістом діяльності відповідного відділу та інструктора фрізичної культури громади з вимогами його посадової інструкції

\begin{tabular}{|c|c|c|c|}
\hline \multirow{2}{*}{ Напрями діяльності } & \multicolumn{3}{|c|}{ Відображення в посадовій інструкції } \\
\hline & Повне & Часткове & Не відображено \\
\hline $\begin{array}{l}\text { Вивчення думки мешканців громади, пов'язаної з розвитком головних напрямів роз- } \\
\text { витку фізичної культури і спорту }\end{array}$ & & & + \\
\hline Планування розвитку фізичної культури і спорту & & + & \\
\hline $\begin{array}{l}\text { Об'рунтування потреби перед керівництвом громади у фінансовому забезпеченні } \\
\text { заходів з розвитку фізичної культури і спорту згідно зі Стратегією розвитку громади }\end{array}$ & & + & \\
\hline $\begin{array}{l}\text { Безпосередня організаційна робота з проведення заходів з фізичної культури і спор- } \\
\text { ту, взаємодія з суміжними фахівцями та активом }\end{array}$ & & + & \\
\hline $\begin{array}{l}\text { Залучення стороннього та узагальнення й активне поширення власного досвіду } \\
\text { підвищення якості фізкультурно-спортивних послуг }\end{array}$ & + & & \\
\hline Вдосконалення матеріально-технічної бази для занять спортом & & & + \\
\hline $\begin{array}{l}\text { Робота з кадрами (направлення на навчання до закладів фізичної культури і спор- } \\
\text { ту випускників шкіл, координація діяльності вже працюючих фахівців, формування і } \\
\text { взаємодія з фізкультурно-спортивним активом) }\end{array}$ & & & + \\
\hline Забезпечення процесу залучення молоді до активних занять спортом & + & & \\
\hline $\begin{array}{l}\text { Сприяння створенню та координація діяльності фізкультурно-спортивних закладів } \\
\text { комунальної власності (ДЮСШ, спортивних клубів) }\end{array}$ & & & + \\
\hline Врахування стану фізкультурно-спортивного життя громади & + & & \\
\hline
\end{tabular}


фрікацій «The European Qualifications Framework, EQF» і європейським стандартом «EuropeActive»[22, 24, 32].

Крім того, існує об'єктивна потреба заснування системи підвищення кваліфрікації і стажування вже працюючих у громадах інструкторів фрізичної культури, адже з 783 фахівців наприкінці 2019 р. лише 261 мали спеціальну вищу освіту, а наприклад, у Хмельницькій області усі 150 інструкторів, які діяли в громадах, взагалі не мали такої освіти [18]. Тож потрібне одночасне створення відповідного Стандарту підвищення кваліфікації працюючих «ннструкторів фрізичної культури сільських і селищних рад, об'єднаних територіальних громад» і на його основі розгортання практики підвищення їхньої кваліфрікації [13].

Уже відпрацьований і виправдав себе у практиці фрізичної культури і спорту підхід, який дозволяє привести існуючий практично «неідеальний об'єКТ» - тут зміст знань, умінь та компетентностей інструкторів фрізичної культури сільських і селищних рад, об'єднаних територіальних громад - до бажаного стану [14]. Пізніше розроблено підхід до управління якістю різних державних послуг [28].

Нами раніше вже було обґрунтовано потребу розробки ряду стандартів як умови високої якості фрізкультурноспортивних послуг, що мають надаватись населенню в умовах створених станом на 2021 р. громад в Україні $[4,5]$.

у розробці Стандарту підвищення кваліфікації «Інструкторів фрізичної культури сільських і селищних рад, об'єднаних територіальних громад» рекомендуємо використати схему проєктування, напрацьовану в сучасній методології, яку застосовують незалежно від об'єкта проєктування [14]:

$$
\begin{gathered}
\Delta \pi p:\left[m \Psi^{\prime} ; m /(\Psi)\right] \rightarrow m 0 ; \\
\Delta B \Pi:\left(\Psi^{\prime} O\right) \rightarrow \Psi,
\end{gathered}
$$

де $\Delta п p$ - процедура проєктування; $\triangle в \Pi$ - процедура впровадження; $m \Psi^{\prime}$ - модель практично неідеального об'єкта $\Psi^{\prime}$ відносно ідеалу $/(\Psi) ; m /(\Psi)$ - модельне формулювання ідеалу; 0 - об'єкт, що проєктується, а саме зміст Стандарту підвищен- ня кваліфікації нині працюючих «/нструкторів фрізичної культури сільських і селищних рад, об'єднаних територіальних громад»; $m 0$ - модель об'єкта, що проєктується, або ж проєкт; Ч _ практично ідеальний об'єкт, тобто Стандарт підвищення кваліфрікації «Інструкторів фрізичної культури сільських і селищних рад, об'єднаних територіальних громад».

При цьому, під $m \Psi^{\prime}$ маємо на увазі знання і уявлення про існуючі знання, вміння та компетентності інструкторів фрізичної культури, які вони повинні мати згідно з наказом Мінмолодьспорту України «Про затвердження Довідника кваліфрікаційних характеристик просресій працівників» [15]; $m /(\Psi)$ - модельні уявлення про обсяг потрібних їм знань, умінь та компетентностей; 0 - зміст підвищення кваліфікації, який проєктується; ПО - Стандарт, що проєктується який розглядаємо як бажаний педагогічний проєкт; Ч - зміст підвищення кваліфрікації інструкторів 3 використанням підготовленого Стандарту підвищення кваліфікації «Інструкторів фрізичної культури сільських і селищних рад, об'єднаних територіальних громад».

Важливим тут є спосіб, у який забезпечується транссормація неідеального об'єкта в ідеальний: $\Psi^{\prime} \rightarrow \Psi$ Таке перетворення є продуктом системного доповнення практично неідеального об'єкта якимось новим об'єктом О. Або ж ситуація, коли об'єкт О впроваджується в структуру $\Psi^{\prime}$ і за рахунок цього перетворюе ії в $\Psi$.

Виходимо з того, що педагогічне проєктування вирішує свої практичні завдання, доповнюючи неідеальну ситуацію $\Psi^{\prime}$ якимось новим об'єктом 0 , що раніше у цій системі був відсутній Принциповим $є$ те, що його не можна знайти шляхом дослідження у $\Psi^{\prime}$, його потрібно створити (спроєктувати). Діяльність зі створення $\mathrm{mO}$ ґрунтується на припущенні про необхідність існування об'єкта О. I це припущення має бути прийняте як робоче у ході здійснення $\Delta п р$. Конкретність у розумінні 0 досягається за допомогою аналізу $m \Psi^{\prime}$ та $m /(\Psi)$, у процесі якого й розкриваються конструктивні ознаки об'єкта О, який передбачається спроєктувати і використовувати на практиці.

Висновки. Серед завдань системи кадрового забезпечення галузі $€$ потреба шляхом стандартизації освіти удосконалити вимоги до змісту, обсягу та якості вищої освіти магістрів, що повною мірою стосується інструкторів 3 фрізкультури сільських і селищних рад, об'єднаних територіальних громад. Відповідно до значного обсягу покладених на цих фрахівців організаційно-методичних функцій, їх не можна розглядати як ізольовано діючих від інших виконавців. Саме тому у Довіднику кваліфікаційних характеристик просресій працівників (Випуск 85 «Спортивна діяльність») чітко вказано, що посада «Методиста з фрізичної культури» передбачає наявність освітнього рівня магістр.

На порядку денному є завдання забезпечити освіту інструкторів-методистів 3 організації фрізкультурнооздоровчої роботи в територіальних громадах як конкурентних фрахівців, здатних досягати мети в різних ситуаціях через опанування інноваційних методів вирішення відповідних професійних завдань, а також наявних певних ссрормованих якостей особи.

Потреба обґрунтування просресійного стандарту інструктора-методиста з організації ффізкультурно-оздоровчої роботи в територіальних громадах зумовлена існуючою відсутністю вкрай потрібного стандартизованого підходу до визначення переліку їхніх трудових функцій, а також загальних і спеціальних компетентностей, що мають їх забезпечувати. В існуючих умовах ця проблема може бути вирішена спеціалізованими ЗВО через розробку ОПП рівня магістр за спеціалізацією «Організація фрізкультурнооздоровчої роботи в територіальних громадах». Крім того, шляхом розробки і використання Стандарту підвищення кваліфрікації діючих «Інструкторів фрізичної культури сільських і селищних рад, об'єднаних територіальних громад».

Перспективи подальших досліджень передбачають обґрунтування впровадження зазначеної ОПП підготовки «Інструкторів-методистів з ор- 
ганізації фрізкультурно-оздоровчої роботи в територіальних громадах», а також Стандарту підвищення кваліфрікації діючих «Інструкторів фрізичної культури сільських і селищних рад, ОТГ» у закладах вищої освіти України.

Конфлікт інтересів. Автор заявляє, що відсутній будь-який конфрлікт інтересів.

\section{ЛITEPATУPA}

1. Алєксєєва IM. Європейські рамки кваліфікацій - опорна конструкція інтеграціі національних систем освіти. Актуальні питання фармацевтичної і медичної науки та практики. 2017;2(24):10:201-6.

2. Данилевич МВ. Теоретичні і методичні засади професійної підготовки майбутніх фахівців з фізичного виховання та спорту до рекреаційно-оздоровчої діяльності [дисертація] Львів: Львівський держ. ун-т фіз. культури; 2018. 534 c.

3. Довідка до питання порядку денного засідання колегії Міністерства молоді та спорту України 4 квітня 2019 року «Про підготовку, перепідготовку та підвищення кваліфікації кадрів у сфері фрізичної культури і спорту» [Інтернет]. [цитовано 2021 бер. 11]. Доступно на: http://komsport.rada.gov.ua/uploads/documents/31954.pdf

4. Дорофеєєва Т. Обґрунтування змісту стандарту розвитку фрізичної культури і спорту в об'єднаних територіальних громадах України Débats scientifiques et orientations prospectives du développement scientifique: collection de papiers scientifique " $\Lambda$ 'ОГО $\Sigma$ » avec de la I conference scientifiques et pratique international. 2021;6:88-93. Vinnitsya-Paris: Platforme scientifique europeene \& La Fedelta.

5. Доросрєєва Т. Вимоги до системи контролю якості надання населенню фрізкультурноспортивних послуг. Interdisciplinary research scientific horizons and perspectives: collection of scientific papers «SCIENTIA» with Proceedings of the I International Scientific and Theoretica Conference. 2021;3:86-96.Vilnius, Republic of Lithuania: European Scientific Platform.

6. Дутчак МВ. Сучасна концепція кадрового забезпечення сфери фрізичної культури і спорту в Україні. Теорія і методика фріз. виховання і спорту. 2020; 2: 124-9. DOI: 10.32652/ tmfvs.2020.2.124-129.

7. Класифрікатор професій України ДК 003:2010 [Інтернет] станом на 26.10.2017 p [цитовано 2021 бер. 8]. Доступно на: https:// buhgalter911.com/uk/spravochniki/klassifikatory/ statisticheskie-klassifikatory/klasifikator-profesiykp-950586.html

8. Куліш НМ. Кадрове забезпечення фізичної культури і спорту в Україні з погляду соціальної сфери. Молодий вчений. 2016.; $1(28): 3: 91-4$.

9. Куроченко ІП. Організація фізичної культури і спорту в об'єднаних територіальних громадах. Київ: ПАЛИВОДА А.В.; 2019. 176 с.

10. Менеджмент і маркетинг у сфері фрі зичної культури та спорту. Освітньо-професійна програма. Харківська державна академія фрізичної культури. Харків, 2017 [Інтернет]. [цитовано 2021 бер. 6]; 16 с. Доступно на: https://khdafk. kh.ua/wp-content/uploads/2020/08/Мен-маг-.pdf
11. Олуйко ВМ. Кадрові процеси у сфері державної служби: можливості регулювання Часопис Хмельницького університету управління та права. 2005;3(15):346-351.

12. Олуйко ВМ. Кадрові процеси в державному управлінні України: стан і перспективи роз витку [дисертація]. Київ: Національна академія державного управління при Президентові України; 2006. 27 с

13. Підвищення кваліфікації та стажування науково-педагогічних працівників Державного ВН3 «Національний гірничий університет». Стандарт вищого навчального закладу. В: Азюковський 00, Конопльова 00, Салов ВО, Сало ва ВО, укладачі. Дніпропетровськ: НГУ; 2015. $25 \mathrm{C}$.

14. Приходько ВВ, Кузьмінський ВП. Креативна валеологія. Концепція і педагогічн технологія формування студентів технічних і гуманітарних спеціальностей як будівничих власного здоров'я: навчальний посібник. Дніпропетровськ: Національний гірничий університет; 2004. 230 c.

15. Про внесення змін до наказу Міністерства молоді та спорту України від 14 грудня 2015 року № 4611. Наказ Міністерства молоді та спорту України від 5 грудня 2017 року № 1470/31338 [Інтернет]. [цитовано 2021 квіт. 1]. Доступно на: https://zakon.rada.gov.ua/laws/ show/z1470-17\#Text

16. Про затвердження Довідника кваліфікаційних характеристик професій працівників, Випуск 85 «Спортивна діяльність». На каз Міністерства молоді та спорту України від 28 жовтня 2016 року № 4080 [Інтернет]. [цито вано 2021 лют. 12]. Доступно на: https://zakon. rada.gov.ua/rada/show/v4080728-16\#Text

17. Про підготовку, перепідготовку та підвищення кваліфікації кадрів у сфрері фрізично культури і спорту. Рішення колегії Міністерства молоді та спорту України від 4 квітня 2919 року [Інтернет]. [цитовано 2021 бер. 13]. Доступно на: http://www.Idufk.edu.ua/index.php/id-2019/ar ticles/zasidannja-kolegiji-ministerstva-molodi-tasportu-ukrajini-89794.html

18. Україна спортивна-2019. Інформаційний довідник [Інтернет]. Київ, 2020 [цитовано 202 бер. 25]; 107 с. Доступно на: https://sport.gov.ua/ storage/app/sites/16/Statystychna_zvitnist/2019. pdf

19. Чеховська ЛЯ. Теоретико-методичн основи організаційного та кадрового забезпечення системи оздоровчого фрітнесу в Україні [дисертація]. Львів: Львівський держ. ун-т фіз культури; 2020. 561 с.

20. Шилова МИ, Белых ИЛ. Формирование конкурентоспособности выпускника вуза. Вестник Томского государственного педагогического университета. 2010;4:39-45.

21. Andreff W. Some Comparative Econo mics of the Organization of Sports: Competition and Regulation in North American vs. European Profes sional Team Sports Leagues. The European Jour nal of Comparative Economics. 2011;8(1):3-27.

22. Carmeli A. Top Management Team Behavioral Integration and the Performance of Servic Organizations. Group and Organization Management. 2008;33(6);712-35.

23. EuropeActive and Deloitte publish European Health \& Fitness Market Report 2017 COLOGNE, GERMANY, 05 APRIL 2017. [cited 2021 Feb 2]. Available from: https://www2.deloitte. com/content/dam/Deloitte/pl/Documents/Press/ EHFMR_2017_Press\%20Release\%20EuropeActive_final.pdf

24. European Commission, 2007. European Model of Sport, Discussion Paper for the Wor- king Group. [cited 2021 Feb 2]. Available from: http://ec.europa.eu/sport/library/documents/b1/ doc424_en.pd

25. Hansen MB, Steen T, Jong M. New Public Management, Public Service Bargains and the challenges of interdepartmental coordination: a comparative analysis of top civil servants in state administration. International Review of Adminis trative Sciences: Intern. journal of comparative publ. administration. 2013;1:29-48.

26. Informacja nt. Programu «Moje Boisko - ORLIK 2012» [cited 2021 Feb 5]. Available from:https://www.msit.gov.pl/pl/aktualnosci/3954 Informacja-nt-programu-Moje-Boisko-ORLIK2012.html

27. Kolev G, Matthes J. Smart fiscal consolidation: a strategy for achieving sustainable public finances and growt. Inst. der deutschen Wirtschaft Köln. Brussels: Centre for European studies; 2013. $115 p$.

28. Maslov D, Nurgatina L. Raising Effectiveness and Quality in Public Administration through Application of the European Common Assess ment Framework (CAF model): Tatarstan Case The 22-nd Conference «From Pre-Weberianism to Neo-Weberianism?», May 22-24, 2014, Budapest Hungary.

29. Ministerstwo Sportu i turystyki. Sprawozdanie z realizacji programu «Moje Boisko ORLIK 2012» za ii polrocze 2010. 52 s.

30. Program «Sportowa Polska» - edycja 2020 rozstrzygnięty! [cited 2021 Mar. 17]. Available from:https://www.gov.pl/web/sport/programsportowa-polska---edycja-2020-rozstrzygniety

31. Projekt Pilotażowy «Animator - Moje Bo isko ORLIK 2012». [cited 2021 Feb 12]. Available from: https://bip.msit.gov.pl/bip/finansowaniezadan/sport-powszechny/2009-rok/308\%2Cprojekt-Pilotazowy-Animator-Moje-Boisko-ORLIK2012.html

32. The European Qualifications Framework [cited 2021 Feb 5]. Available from: https://europa eu/europass/en/european-qualifications-framework-eqf

33. Utrzymywanie przez gminy obiektów wybudowanych w ramach programu «Moje Boisko ORLIK 2012». Departament nauki, oświaty i dziedzictwa narodowego. Warszawa; 2018. 73 s.

34. Standards of Conduct for Internationa Civil Service. [cited 2021 Mar. 19]. Available from: http://unesdoc.unesco.org/images/0014/001497/ 149745e.pdf.

35. Vass Z, Boronyai Z, Csanyi T. European Framework of Quality Physical Education. European Physical Education Association; 2018. 24 p.

\section{LITERATURE}

1. Alieksieieva IM. The European Qualifications Framework is the mainstay of integration of national education systems. Current issues of pharmaceutical and medical science and practice. 2017;2(24):10:201-6.

2. Danylevych MV. Theoretical and methodological principles of professional training of future specialists of physical education and sports for recreational and health-enhancing activities [dissertation]. Lviv: Lviv state un-ty of physical culture; 2018. 534 p.

3. Reference information for the agenda item of the meeting of the Board of the Ministry of Youth and Sports of Ukraine on April 4, 2019 «On training retraining, and advanced training of personnel in the field of physical culture and sports» [Internet] [cited on March 11, 2021]. Retrieved from: http:// 
komsport.rada.gov.ua/uploads/documents/31954 pdf

4. Dorofieieva T. Substantiation of the content of the standard of development of physical culture and sports in the united territorial communities of Ukraine. Débats scientifiques et orientations prospectives du développement scientifique: collection de papiers scientifique " $\Lambda \mathrm{O} \Gamma \mathrm{O} \Sigma$ » avec de la I conference scientifiques et pratique international. 2021;6:88-93. Vinnitsya-Paris: Platforme scientifique europeene \& La Fedelta.

5. Dorofieieva T. Requirements for the quality control system for the provision of physical culture and sports services to the population. Interdisciplinary research: scientific horizons and perspectives: collection of scientific papers «SCIENTIA " with Proceedings of the I International Scientific and Theoretical Conference. 2021;3:86-96.Vilnius, Republic of Lithuania: European Scientific Platform.

6. Dutchak MV. Modern concept of human resourcing the sphere of physical culture and sport in Ukraine. Theory and methods of physical education and sports. 2020; 2: 124-9. DOl: 10.32652/ tmfvs.2020.2.124-129.

7. Classifier of Occupations of Ukraine DK 003:2010 [Internet]. actual on 26.10.2017 [cited on March 8, 2021]. Retrieved from: https:// buhgalter911.com/uk/spravochniki/klassifikatory/ statisticheskie-klassifikatory/klasifikator-profesiy$\mathrm{kp}-950586 . \mathrm{html}$

8. Kulish NM. Human resourcing of physical culture and sport in Ukraine in terms of socia sphere. Young scientist. 2016:;1(28):3:91-4

9. Kurochenko IP. Organization of physical culture and sports in the united territorial communities of Ukraine. Kyiv: PALYVODA A.V.; 2019 $176 \mathrm{p}$.

10. Management and marketing in the field of physical culture and sports. Educational and professional program. Kharkiv State Academy of Physical Culture. Kharkiv, 2017 [Internet]. [cited on March 6, 2021]. 16 p. Retrieved from: https:// khdafk.kh.ua/wp-content/uploads/2020/08/Менмar-.pdf

11. Oluyko VM. Personnel processes in the civil service: opportunities for regulation. Chasopys Khmelnytskoho universytetu upravlinnya ta prava. 2005;3(15):346-351.

12. Oluyko VM. Personnel processes in public administration of Ukraine: state and prospects of development [dissertation]. Kyiv: National Academy for Public Administration under the President of Ukraine; 2006; 27 p.
13. Advanced training and practical training of research and teaching personnel of the State higher eduction institution «National Mining University». Standard of higher eduction institution. In Aziukovskyi 00, Konopliova 00, Salov V0, Salova V0, compilers. Dnipropetrovsk: NMU; 2015; 25 p.

14. Prykhodko VV, Kuzminskyi VP. Creative valeology. The concept and pedagogical technology of teaching students of technical and humanitarian specialties as creators of their own health: study guide. Dnipropetrovsk: National mining university; 2004. 230 p.

15. On amendments to the order of the Ministry of Youth and Sports of Ukraine on December 14 2015 No. 4611. The order of the Ministry of Youth and Sports of Ukraine on December 5, 2017 No 1470/31338 [Internet]. [cited on April 1, 2021] Retrieved from: https://zakon.rada.gov.ua/laws/ show/z1470-17\#Text

16. On the approval of the Handbook of qualification characteristics of occupations, Issue 85 «Sporting activity». The order of the Ministry of Youth and Sports of Ukraine on October 28, 2016 No. 4080 [Internet]. [cited on February 12, 2021] Retrieved from: https://zakon.rada.gov.ua/rada/ show/v4080728-16\#Text

17. On training, retraining, and advanced training of professionals in the field of physical culture and sports. Decision of the collegium of the Ministry of Youth and Sports of Ukraine on April 4, 2019. [Internet]. [cited on March 13 2021]. Retrieved from: http://www.Idufk.edu.ua/ index.php/id-2019/articles/zasidannja-kolegijiministerstva-molodi-ta-sportu-ukrajini-89794 html

18. Sports Ukraine-2019. Information guide. [Internet]. Kyiv, 2020 [cited on March 25, 2021] 107 p. Retrieved from: https://sport.gov.ua/ storage/app/sites/16/Statystychna_zvitnist/2019. pdf

19. Chekhovska LYa. Theoretical and metho dological principles of organizational and staffing support for the system of health-enhancing fitness in Ukraine [dissertation]. Lviv: Lviv state un-ty of physical culture; 2020. $561 \mathrm{p}$.

20. Shilova MI, Belykh IL. Development of competitive advantage of a university graduate. Tomsk State Pedagogical University Bulletin. 2010;4:39-45.

21. Andreff W. Some Comparative Econo mics of the Organization of Sports: Competition and Regulation in North American vs. European Profes sional Team Sports Leagues. The European Journal of Comparative Economics. 2011;8(1):3-27.

\section{ІНФОРМАЦІЯ ПРО АВТОРА}

Дорофєєва Тетяна Іванівна ORCID.0RG/0000-0001-9025-5645, dti16071981@gmail.com Харківська державна академія фрізичної культури 61058, Харків, вул. Клочківська, 99

\section{INFORMATION ABOUT THE AUTHOR}

Dorofieieva Tetiana ORCID.0RG/0000-0001-9025-5645, dti16071981@gmail.com Kharkiv State Academy of Physical Culture Klochkivska str. 99, Kharkiv, 61058, Ukraine
22. Carmeli A. Top Management Team Behavioral Integration and the Performance of Service Organizations. Group and Organization Management. 2008;33(6);712-35.

23. EuropeActive and Deloitte publish European Health \& Fitness Market Report 2017. COLOGNE, GERMANY, 05 APRIL 2017. [cited 2021 Feb 2]. Available from: https://www2.deloitte. com/content/dam/Deloitte/pl/Documents/Press/ EHFMR_2017_Press\%20Release\%20EuropeActive_final.pdf

24. European Commission, 2007. European Model of Sport, Discussion Paper for the Working Group. [cited 2021 Feb 2]. Available from: http://ec.europa.eu/sport/library/documents/b1/ doc424_en.pdf

25. Hansen MB, Steen T, Jong M. New Public Management, Public Service Bargains and the challenges of interdepartmental coordination: a comparative analysis of top civil servants in state administration. International Review of Administrative Sciences: Intern. journal of comparative publ. administration. 2013;1:29-48.

26. Informacja nt. Programu «Moje Boisko - ORLIK 2012» [cited 2021 Feb 5]. Available from: https://www.msit.gov.pl/pl/ aktualnosci/3954,Informacja-nt-programu-MojeBoisko-ORLIK-2012.html

27. Kolev G, Matthes J. Smart fiscal consolidation: a strategy for achieving sustainable public finances and growt. Inst. der deutschen Wirtschaft Köln. Brussels: Centre for European studies; 2013. $115 p$

28. Maslov D, Nurgatina L. Raising Effectiveness and Quality in Public Administration through Application of the European Common Assessment Framework (CAF model): Tatarstan Case. The 22-nd Conference «From Pre-Weberianism to Neo-Weberianism?», May 22-24, 2014, Budapest, Hungary.

29. Ministerstwo Sportu i turystyki. Sprawozdanie z realizacji programu «Moje Boisko ORLIK 2012» za ii polrocze 2010. $52 \mathrm{~s}$

30. Program «Sportowa Polska» - edycja 2020 rozstrzygnięty! [cited 2021 Mar. 17]. Available from:https://www.gov.pl/web/sport/programsportowa-polska---edycja-2020-rozstrzygniety

31. Projekt Pilotażowy «Animator - Moje Boisko ORLIK 2012». [cited 2021 Feb 12]. Available from: https://bip.msit.gov.pl/bip/finansowaniezadan/sport-powszechny/2009-rok/308\%2Cprojekt-Pilotazowy-Animator-Moje-Boisko-ORLIK2012.html

32. The European Qualifications Framework. [cited 2021 Feb 5]. Available from: https://europa. eu/europass/en/european-qualifications-framework-eqf

33. Utrzymywanie przez gminy obiektów wybudowanych w ramach programu «Moje Boisko ORLIK 2012». Departament nauki, oświaty i dziedzictwa narodowego. Warszawa; 2018. 73 s.

34. Standards of Conduct for International Civil Service. [cited 2021 Mar. 19]. Available from: http://unesdoc.unesco.org/images/0014/ 001497/149745e.pdf

35. Vass Z, Boronyai Z, Csanyi T. European Framework of Quality Physical Education. European Physical Education Association; 2018. 24 p.

Надійшла 01.09.2021 